\title{
USE OF A LASER DISC FOR CUTTING SILICON WAFERS
} \section{UPORABA LASERSKEGA DISKA ZA REZANJE SILICIJEVIH REZIN}

\author{
Malgorzata Musztyfaga-Staszuk ${ }^{1}$, Damian Janicki' ${ }^{1}$, Piotr Panek², Maciej Wiśniowski ${ }^{3}$ \\ ${ }^{1}$ Silesian University of Technology, Welding Department, 18a Konarskiego Street, 44-100 Gliwice, Poland \\ ${ }^{2}$ Insitute of Metallurgy and Materials Science, Polish Academy of Sciences, Krakowska 22, 43-340 Kozy, Poland \\ ${ }^{3}$ Silesian University of Technology, Institute of Engineering Materials and Biomaterials, Konarskiego street 18a, 44-100 Gliwice, Poland \\ malgorzata.musztyfaga@polsl.pl
}

Prejem rokopisa - received: 2017-05-05; sprejem za objavo - accepted for publication: 2017-09-07

doi:10.17222/mit.2017.052

Research studies in the photovoltaic field aim to reduce the costs of electrical energy with the use of photovoltaic cells to the level competitive with the costs of energy produced from conventional energy sources. It is necessary to eliminate the technological process with expensive and difficult-to-automate operations and replace it with a cheap one, whose production can be automated to obtain the above objective. Laser processing has become the key technology for the industrial production of crystalline solar cells. Lasers are mainly used in photovoltaics for cutting wafers or silicon films, glass panels and thin-film modules. The article presents the preliminary understanding of the influence of laser cutting on the quality of silicon-wafer cut edges to ensure their minimum deformation. This paper presents an application of lasers in photovoltaics, mainly including laser-cutting issues, analyzed to improve the quality of the edges of silicon wafers cut with a laser disk rarely used for such a purpose.

Keywords: laser cutting, silicon wafers, confocal laser-scanning microscope, scanning electron microscope

Raziskovalne študije na področju fotovoltaike se v zadnjem času ukvarjajo predvsem z zmanjševanjem stroškov proizvodnje električne energije $\mathrm{z}$ uporabo fotovoltaičnih celic na nivoju, ki bi bil konkurenčen stroškom proizvodnje energije proizvedene na konvencionalen način. Za to je potrebno odstraniti tehnološki proces, ki vsebuje drage in za avtomatizacijo težavne delovne operacije in jih zamenjati s cenejšimi, ki jih je možno avtomatizirati. Lasersko procesiranje postaja ključna tehnologija v industrijski proizvodnji kristaliničnih sončnih celic. Laserji se v fotovoltaiki v glavnem uporabljajo za rezanje Si rezin ali filmov, steklenih panelov in modulov s tankimi filmi. Moduli s tankimi filmi (angl.: thin-film modules) so v fotovoltaiki mišljeni moduli sončnih celic druge generacije, pri kateri je v obliki več tankih plasti oz. tankih filmov na substratu (steklo, plastika ali kovina) nanešen fotovoltaični material. V članku avtorji predstavljajo uvodno razumevanje vpliva laserskega rezanja na ostrino robov Si rezin, ki zagotavlja njihovo minimalno deformacijo. Predstavljena je uporabnost laserjev v fotovoltaiki s poudarkom na laserskem rezanju in analizi izboljšanja kvalitete robov pri rezanju Si rezin z laserskim diskom, ki se redko uporablja za ta namen.

Ključne besede: lasersko rezanje, silicijeve rezine, konfokalni laserski vrstični mikroskop, vrstični elektronski mikroskop

\section{INTRODUCTION}

Laser processing has become the key technology for the industrial production of crystalline solar cells. ${ }^{1}$ Crystalline silicon wafers can be cut with very high precision and low heat input, using the same ablation process as edge isolation. Laser cutting is one of the thermal-material-separation methods used to produce the elements, which are used, without additional processing, for further processing. Laser cutting progresses at high speed, without any cracks and with the greatest precision, while minimizing the damage caused by the spot introduction of energy and high-energy stream cutting to compensate for the part during its machining or cutting. ${ }^{2-5}$

This paper presents fragments of the theory of the application of lasers in photovoltaics, ${ }^{6,7}$ mainly including laser-cutting issues, used to analyze the improved quality of cut edges of silicon wafers with a laser disc rarely used for such a purpose. The principle of the laser-disc technique allows the determination of the influence of the laser micro-treatment on the quality of cut edges of silicon wafers, ensuring their minimum deformation. ${ }^{8-10}$
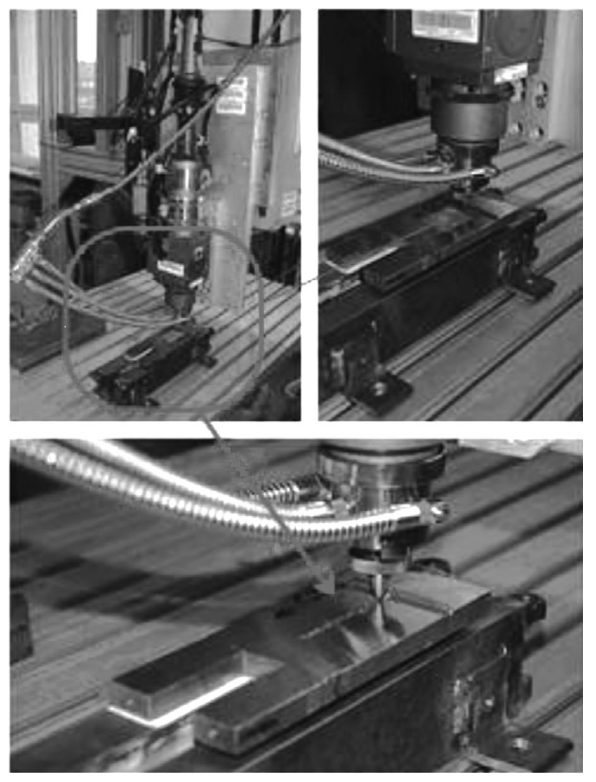

Figure 1: Laboratory set-up for cutting silicon wafers including a laser disk produced by TruDisk Trumpf 3302 
For this purpose, the following steps were performed: the topography of both the surface and the cross-section of the formed edges of the wafers was observed with a laser using a scanning electron microscope; the width of the interstice of the cut wafers was measured using a stereoscopic light microscope; the roughness of the cut surface of the cross-section of a sample was measured using a confocal laser-scanning microscope.

\section{EXPERIMENTAL PART}

The structures were fabricated on $1-\Omega \mathrm{cm}$ p-type Cz-Si (100), 180- $\mu$ m-thick wafers. The wafers have dimensions of $5 \times 5 \mathrm{~cm}^{2}$ and textured or polished surfaces.

Table 1: Technical parameters of the laser

\begin{tabular}{|l|c|}
\hline Rated output power (continuous radiation) $(\mathrm{W})$ & 3300 \\
\hline Output regulation $(\mathrm{W})$ & $80-3300$ \\
\hline Irradiation wavelength $(\mathrm{nm})$ & 1030 \\
\hline Focal length $(\mathrm{mm})$ & 200 \\
\hline Diameter of the focused laser beam $(\mu \mathrm{m})$ & $200 / 100$ \\
\hline Quality factor of the BPP $(\mathrm{mm} / \mathrm{mrad})$ & 8 \\
\hline
\end{tabular}

Table 2: Conditions of laser cutting of monocrystalline silicon with stable parameters such as wafer thickness $\mathrm{Si}=240 \mu \mathrm{m}$, laser power $v=80 \mathrm{~W}$, the distance between the nozzle and the surface of a wafer of $450 \mu \mathrm{m}$

\begin{tabular}{|c|c|c|c|c|}
\hline \multirow{2}{*}{ No. } & \multirow{2}{*}{$\begin{array}{c}\text { Cutting } \\
\text { speed } \\
\text { (m/min })\end{array}$} & $\begin{array}{c}\text { Atmosphere } \\
(\mathrm{Pa})\end{array}$ & $\begin{array}{c}\text { Width of the interstice }(\mathrm{mm}) \\
\text { from the back } \\
\text { of laser cutting }\end{array}$ & $\begin{array}{c}\text { from the face of } \\
\text { laser cutting }\end{array}$ \\
\hline 1 & 1 & 50,000 & - & - \\
\hline 2 & 3 & 50,000 & - & - \\
\hline 3 & 1 & 100,000 & 0.19 & 0.27 \\
\hline 4 & 1 & 150,000 & 0.19 & 0.27 \\
\hline 5 & 0.5 & 300,000 & 0.16 & 0.27 \\
\hline 6 & 1.5 & 300,000 & 0.2 & 0.27 \\
\hline 7 & 2 & 300,000 & - & - \\
\hline 8 & 2.5 & 300,000 & - & - \\
\hline 9 & 3 & 300,000 & 0.2 & 0.29 \\
\hline 10 & 0.5 & 510,000 & - & - \\
\hline 11 & 1 & 510,000 & - & 0.27 \\
\hline 12 & 0.5 & 610,000 & 0.16 & \\
\hline
\end{tabular}

where: (-) means a delamination of the interstice or an occurrence of chipping
Table 3: Preliminary conditions of laser cutting of monocrystalline silicon with stable parameters such as laser power $v=80 \mathrm{~W}$, the distance between the nozzle and the surface of a wafer of $450 \mu \mathrm{m}$

\begin{tabular}{|c|c|c|c|}
\hline No. & $\begin{array}{c}\text { Silicon thickness } \\
(\mu \mathrm{m})\end{array}$ & $\begin{array}{l}\text { Cutting speed } \\
(\mathrm{m} / \mathrm{min})\end{array}$ & $\begin{array}{c}\text { Process gas } \\
(\mathrm{Pa})\end{array}$ \\
\hline 1 & \multirow{5}{*}{180} & 1 & 200,000 \\
\hline 2 & & 1.5 & 200,000 \\
\hline 3 & & 2 & 200,000 \\
\hline 4 & & 0.5 & 510,000 \\
\hline 5 & & 1 & 510,000 \\
\hline 6 & \multirow{3}{*}{190} & 2 & 510,000 \\
\hline 7 & & 3 & 510,000 \\
\hline 8 & & 4 & 510,000 \\
\hline
\end{tabular}

A range of silicon-wafer thicknesses was used for experimental testing. The silicon wafers were laser cut using a laser disc (Figure 1). The basic characteristic data of the device are summarized in Table 1. Tables 2 and $\mathbf{3}$ present the micromachining conditions of monocrystalline silicon.

\section{RESULTS AND DISCUSSION}

As a result of the metallographic investigations carried out using a light microscope, it was found that the minimum width of the interstice for the face and back of a cut wafer surface was obtained with process-gas pressure of $0.3 \mathrm{MPa}$ and a cutting speed of $1.5 \mathrm{~m} / \mathrm{min}$ (Table 2). In the case of the face of a cut wafer surface, it was found that the minimum and maximum width values for the interstice equal $0.27 \mathrm{~mm}$ and $0.29 \mathrm{~mm}$. In the case of the back of a cut wafer surface, it was found that the minimum and maximum width values for the interstice equal $0.16 \mathrm{~mm}$ and $0.20 \mathrm{~mm}$.

Figure 2 shows that the width of the interstice for the face and back of a cut wafer surface is in the normal range. The investigated cut silicon surface is presented in Figure 2a, together with the overhanging cutting products at the cross-section of the sample. When we look at Figure 2b, relating to the back of the cut wafer surface, we can observe a slight cooling effect caused by the applied process gas - argon.
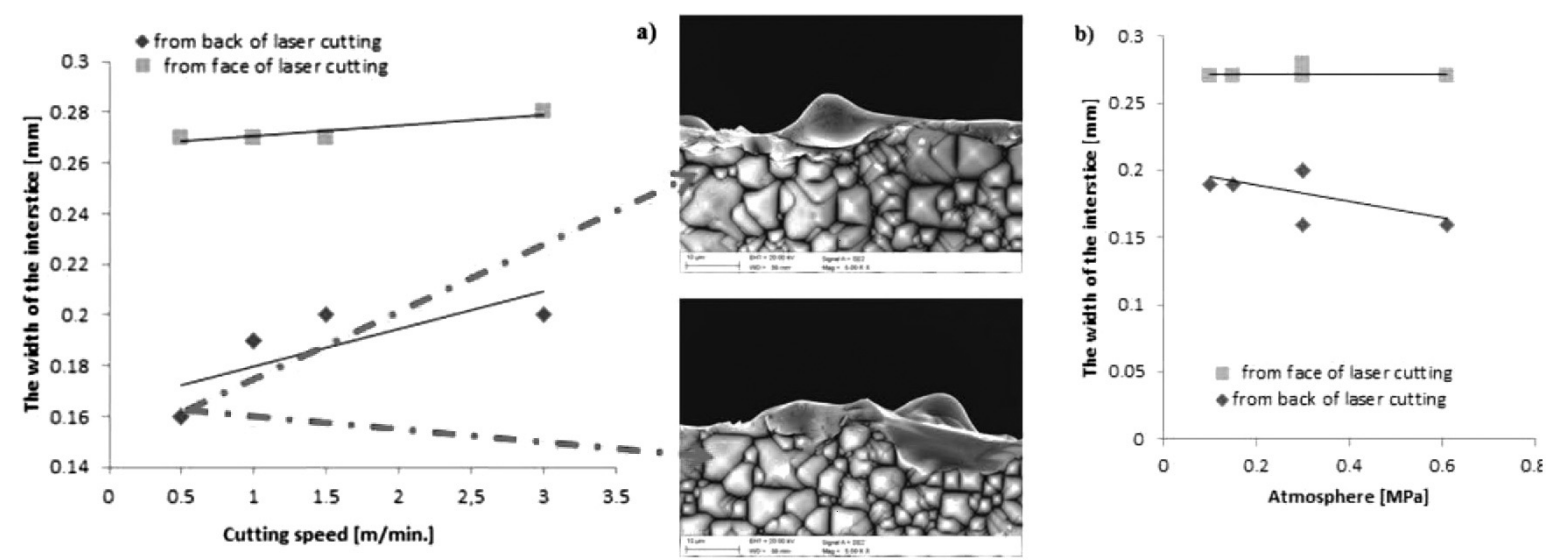

Figure 2: Width of the interstice depending on: a) laser-beam feed rate, b) process gas 
a)
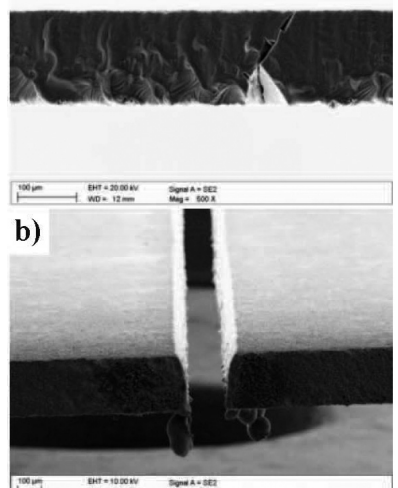

c)

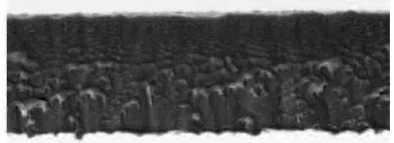

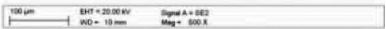
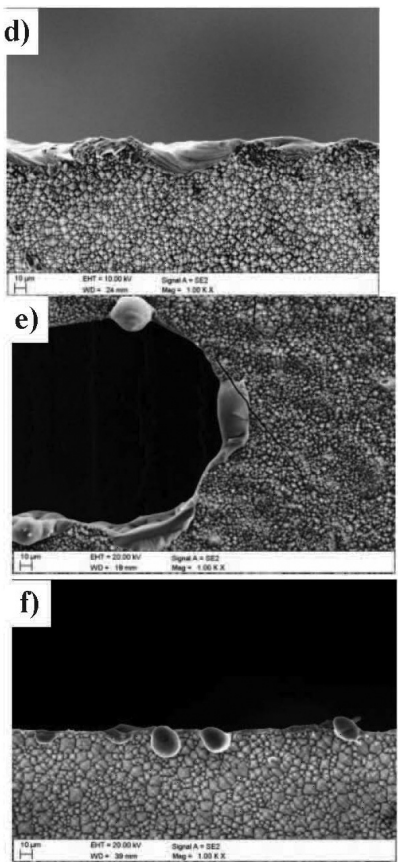

Figure 3: SEM images: a), b), c), d) and f) fracture; e) surface topography of a silicon-wafer laser cut

Fracture observations of the cut edges of a silicon wafer obtained with the scanning electron microscope present a non-uniformly melted structure similar to a porous one, often of an irregular shape (Figure 3a to $\mathbf{3 c}$ ). An especially large agglomerate of overhanging cutting products at the cross-section of the sample is presented in Figure 3b. Similar agglomerates are presented one by one at different distances along the cutting line on the back of the cut wafer surface (Figure 3d to $3 \mathbf{f}$ ).

The agglomerates occurred individually in the middle of a silicon sample (Figure $\mathbf{4 b}$ ) or formed combined concentrations of two or more agglomerates on the upper part of a sample cut out by laser (Figure 4a). Surface observations obtained with scanning electron microscopy
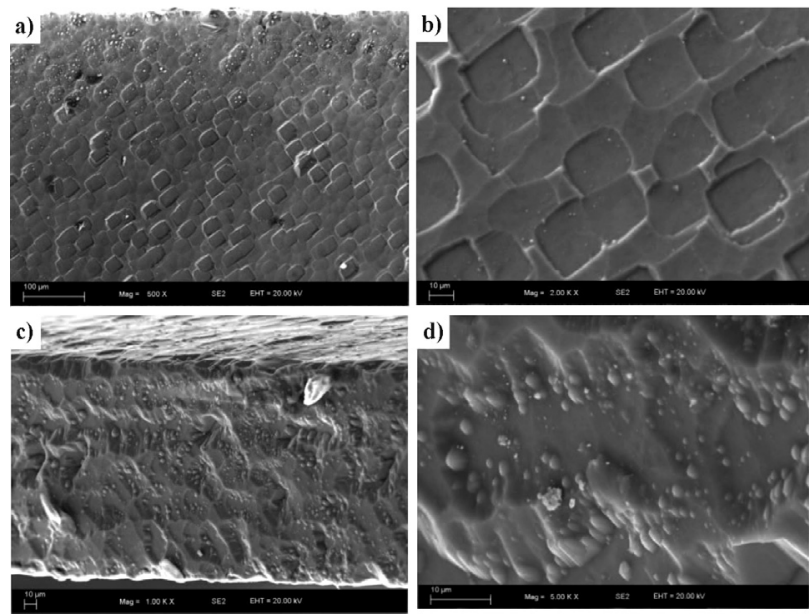

Figure 4: SEM images: a), b) surface topography; c, d) fracture of the edge of a silicon wafer laser cut at a cutting speed of $4 \mathrm{~m} / \mathrm{min}$ and a laser beam of $80 \mathrm{~W}$ (Table 3, No. 8)
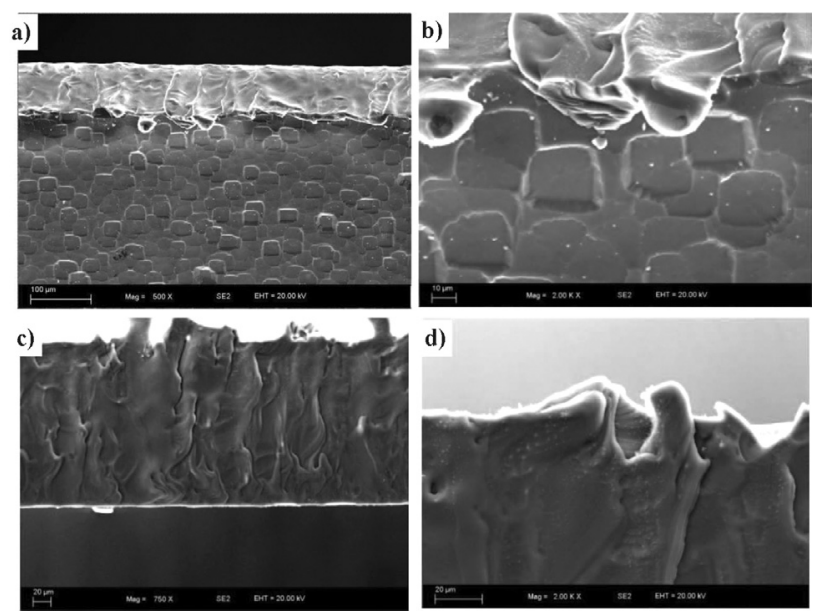

Figure 5: SEM images: a), b) surface topography; c, d) fracture at the edge of a silicon wafer laser cut at a cutting speed of $0.5 \mathrm{~m} / \mathrm{min}$ and the laser beam of $80 \mathrm{~W}$

of the cut edges of silicon wafers revealed uniformly melted structures without pores or discontinuity, often of an irregular shape (Figure $\mathbf{4 c}$ and $\mathbf{4 d}$ ).

Based on the metallographic investigations carried out with the scanning electron microscope, we found some non-uniformity, which is associated with the occurrence of individual agglomerates in the shape of solidified silicon balls of diversified sizes in a range from a few to several microns (Figure 5a and 5b). The agglomerates are presented one by one on the whole surface of a silicon sample (Figure 5a). Surface observations of the cut edges of the silicon wafer obtained with the scanning electron microscope show a non-uniformly melted structure similar to a porous one, often with an irregular shape (Figure 5c and 5d) and microcracks (Figure 5d).

Confocal-laser-scanning-microscope investigations confirm that the most porous structure from the face to
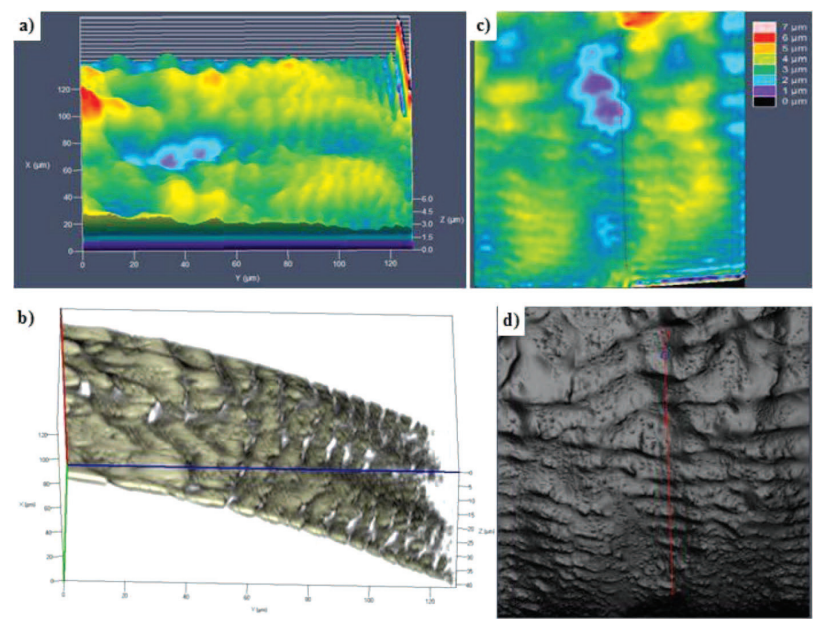

Figure 6: Three- $(\mathrm{a}, \mathrm{b})$ and two- $(\mathrm{c}, \mathrm{d})$ dimensional cross-section surface (CLSM) of a silicon wafer laser cut with the following parameters: cutting speed of $0.5 \mathrm{~m} / \mathrm{min}$ and process-gas pressure of $610,000 \mathrm{~Pa}$ 
the back of a cut wafer surface is $7 \mu \mathrm{m}$ (Figure 6a and 6b).

The roughness of the cross-section of a cut surface was determined by checking the height profile of a two-dimensional surface measured with the confocal laser-scanning microscope (Figure $\mathbf{6 c}$ and $\mathbf{6 d}$ ). The roughness-measurement result for the chosen sample is $0.32 \mu \mathrm{m}$.

To recapitulate, the edge of a silicon wafer cut with a laser at the maximum feed rate of the laser beam led to a more uniform structure than in the case, where the silicon wafer was cut at the minimum feed rate of the laser beam.

\section{CONCLUSIONS}

Given the increasing demand for materials with appropriate properties, laser technology can be considered, from the scientific point of view, as a valid way of cutting silicon, for example. In the production of solar cells, laser technology creates a possibility for micromachining the material and its surface thanks to the use of a laser beam as a non-contact, automated tool for its shaping.

\section{Acknowledgment}

This research was financed by the Ministry of Science and Higher Education of Poland with a statutory financial grant of the Faculty of Mechanical Engineering, SUT, in 2017 and co-founded from Norway
Grants in the frame of Contract No. POLNOR/199380/ 89/2014.

\section{REFERENCES}

${ }^{1}$ P. Romero, N. Otero, I. Coto, C. Leira, A. Gonzáleza, Experimental study of diode laser cutting of silicon using water assisted thermally driven separation mechanism, Physics Procedia, 41 (2013), 617-626, doi:10.1016/j.phpro.2013.03.124

${ }^{2}$ A. Lisiecki, Welding of thermomechanically rolled fine-grain steel by different types of lasers, Arch. Metall. Mater., 59 (2014) 4 , 1625-1631, doi:10.2478/amm-2014-0276

${ }^{3}$ M. Musztyfaga-Staszuk, L. A. Dobrzański, The use of laser technology to shape properties of the contacts of silicon solar cells and their structure, Central European Journal of Physics, 12 (2014) 12, 836-842, doi: $10.2478 / \mathrm{s} 11534-014-0512-5$

${ }^{4}$ P. H. Drive, Laser Systems and Processes within Next Generation Photovoltaic Manufacturing Equipment, 4th Photovoltaic Manufacturing Technology Conference, 2008, 1-6

${ }^{5}$ P. Panek, K. Drabczyk, J. Kwiatkowska, P. R. Socha, The Al-Si laser fired point contacts for application in crystalline silicon solar cells, Electronics: structures, technologies, applications, 51 (2010) 5, 37-41

${ }^{6}$ Laser Cutting of Solar Cells, https://www.rofin.com/en/markets/ solar_industry/laser_cutting/, 9. 5. 2016

${ }^{7}$ R. Hendel, Laser Applications in Solar Cell Manufacturing, Focus: Laser Micro Processing, 1 (2008), 32-35

${ }^{8}$ K. Salonitis, A. Stournaras, G. Tsoukantas, P. Stavropoulos, G. Chrysolouris, A theoretical and experimental investigation on limitations of pulsed laser drilling, Journal of Materials Processing Technology, 183 (2007) 1, 96-102

${ }^{9}$ T. Stechnij, S. Zaborski, The influence of temperature gradients during the laser cutting of photovoltaic silicon plates on the properties of silicon cells, Power engineering, (2014), 692-694

${ }^{10}$ T. Stechnij, S. Zaborski, D. Poroś, Comparison of selected conventional and unconventional methods of silicon cutting, Mechanik, 4 (2015), 190-195 